\title{
Responses of Pinus pinea seedlings to moderate drought and shade: is the provenance a differential factor?
}

\author{
M. PARDOS ${ }^{+}$and R. CALAMA \\ Dept. of Silviculture and Forest System Management, INIA-CIFOR, Crtra Coruña Km 7.5, 28040-Madrid, Spain
}

\begin{abstract}
The widespread Mediterranean Pinus pinea showed exceptionally low genetic diversity and low differentiation between traits in the adult phase. We explored the adaptation potential of seedlings from four main Iberian provenances during their regeneration phase. We assessed the variability of shoot growth, allometry, physiological traits, and phenotypic plasticity to the interactive effect of light and water environments during 8-month moderate water-stress cycle and after one-week heat wave. The effect of shade and drought was mainly orthogonal whatever the provenance. The inland La Mancha provenance showed higher shoot growth and biomass compared to the southern coastal Depresión-delGuadalquivir provenance. Following the heat wave, La Mancha presented higher net photosynthetic rates, a lower decrease in maximal quantum efficiency of PSII, and a higher accumulated relative height growth, thus, showing an adaptive advantage. The observed differences corroborated the ecological grouping of the provenances along latitudinal and inlandcoastal gradients. We confirmed the high adaptive plasticity of Pinus pinea to the unpredictable Mediterranean environment.
\end{abstract}

Additional key words: adaptive plasticity; gas exchange; heat shock; latitudinal gradient; light-response curves; Mediterranean stone pine.

\section{Introduction}

Latest climate change scenario projections for Europe suggest a temperature increase and changes in the precipitation regime that can be especially noticeable in the Mediterranean region (Lindner et al. 2010, Spathelf et al. 2014), thus showing its higher vulnerability to climate change than other regions in Europe (Lindner and Calama 2013). Mediterranean forests are already highly constrained by dry conditions and high solar loads, mainly in the summer. In fact, summer drought is recognized as the major stress, limiting plant species distribution and growth in all Mediterranean regions (Sabaté et al. 2002). Thus, the differential ability of Mediterranean species to cope with the complex phenomenon of interactions between light and water, particularly, during the initial stages of development, is a key trait governing community structure and dynamics (Sánchez-Gómez et al. 2006).

The complex interactions and trade-offs between light and soil water availability have helped to determine the optimal regeneration niche of a wide range of forest species (e.g. Sack 2004, Valladares et al. 2005, Calama et al. 2013, Mayoral et al. 2015). The synergistic effect of air temperature in combination with drought and solar radiation should not be forgotten, as high temperature extremes in the Mediterranean climate restrict productivity and influence species distribution (Rubio-Casal et al. 2010). Under such conditions, high temperature stress is superimposed on the light stress, which makes the situation more complicated and difficult. Photosystem II is brought into a severe stress conditions and avoidance of the light stress is difficult, provoking reversible

Received 4 July 2016, accepted 6 March 2017, published as online-first 4 May 2017.

${ }^{+}$Corresponding author: phone: +34913473990; fax: +34913476767; e-mail: pardos@inia.es

Abbreviations: $E$ - transpiration rate; ETR - apparent phtosynthetic electron transport rate; $\mathrm{F}_{\mathrm{v}} / \mathrm{F}_{\mathrm{m}}$ - maximum photochemical efficiency of PSII; $g_{\mathrm{s}}$ - stomatal conductance; $\mathrm{H}$ - soil moisture; LA - leaf area; LDM - leaf dry mass; LMF - leaf mass fraction; $P_{\mathrm{N}}-$ net assimilation rate; $P_{\mathrm{gmax}}-$ maximum rate of gross photosynthesis at saturating irradiance; $R_{\mathrm{D}}$ - dark respiration; RDM - root dry mass; RHG - accumulated relative height growth; RMF - root mass fraction; SDM - stem dry mass; ShDM - shoot dry mass; ShMF - shoot mass fraction; SLA - specific leaf area; SMF - stem mass fraction; S/R - shoot to root ratio; TDM - total dry mass; $\alpha$ - quantum yield of assimilation; $\Phi_{\text {PSII }}$ - yield of photochemistry in PSII; $\psi_{\text {pd }}$ - predawn water potential.

Acknowledgements: This study was supported by the Spanish National Programme for Fundamental Research Projects (Projects no. AGL2010-15521 and RTA2013-00011-C02-01). We are especially grateful to M. Conde, G. Madrigal, and E. Garriga for technical support in the greenhouse. 
photoinhibition (Yamamoto 2016). Thus, during the hot, dry summer, light reduction under forest canopies reduces air temperature and evaporative demand, ameliorating the water stress conditions (Valladares et al. 2005). Shade also prevents damage to the photosynthetic apparatus provoked by excessive radiation, which cannot be used in assimilatory processes when $\mathrm{CO}_{2}$ uptake is limited under drought conditions (Demmig-Adams and Adams 1992, Cuesta et al. 2010). However, during the favorable wet season, shade reduces photosynthetic assimilation, decreasing absolute root growth (Puértolas et al. 2010). Low radiation also increases the proportion of carbon allocated to aboveground photosynthetic tissues, reducing the ratio between water uptake and water loss in the plant (Gardiner and Hodges 1998).

The role of forest management within the context of global climate change includes management approaches that intend to mitigate it by enhancing carbon storages and to foster adaptation by maintaining compositionally and structurally complex forests (D'Amato et al. 2011). Among adaptation options, forest regeneration offers a direct and immediate opportunity to select provenances that can be better adapted or adaptable to the changing climatic conditions (Lindner et al. 2008) and that show a plastic response to the environment (Valladares et al. 2000). Regeneration is a stage at which the species and genetic composition of the stand are established, where diversity can be manipulated the most. Although later silvicultural steps may modify to some extent the initial composition, they cannot correct if the genetic range available at the site is insufficient for current or future site conditions (Lindner et al. 2008).

Mediterranean stone pine (Pinus pinea L.) is a widespread species in the Mediterranean area growing in contrasting environments and shows a remarkable tolerance to adverse conditions, such as drought and extreme or late frost, both in the adult and the regeneration phases (Court-Picon et al. 2004, Pardos et al. 2010, Pardos et al. 2014, Loewe et al. 2015). Traditional even-aged stand management in stone pine follows a natural regenerationbased silviculture, focusing mainly on seed production with the purpose of harvesting its edible seeds. Such

\section{Material and methods}

Plant material and treatments: The study was conducted on 2.5-year-old plants from four main provenances of Pinus pinea L. in Spain: Meseta Norte (MN), Cataluña Litoral (CL), Depresión del Guadalquivir (DG), and La Mancha (LM), representing different locations along a climate gradient along the natural range of the species in Spain (Fig. 1). Plants older than two years were used in this experiment since once seedlings reach this age in forests, their survival is around 85-89\% (Mayoral et al. 2015) and natural regeneration is highly likely. Plants were raised from seeds and grown in the nursery at INIA (Madrid, 40²7'20' 'N, 344'58'’'W, $595 \mathrm{~m}$ a. s. 1.) for two intensive management has been historically responsible for the regeneration failure in the long term, due to the low densities of the stands during the regeneration period (Gordo et al. 2012). A recent stochastic multistage regeneration model developed by Manso et al. (2014) for stone pine recommends a progressive and flexible removal of the parent trees in order to release seedlings and saplings from understory shade. This progressive release can produce different environmental conditions (e.g. in the light and water availability environments) during the regeneration phase that forest managers should be able to manipulate in order to improve survival and growth.

In this study, we tried to identify differences in shoot growth, allometry, and physiological adaptive traits between stone pine seedlings from four main Iberian provenances, under changing water and light conditions, mimicking the environmental conditions found at stone pine stands, in order to identify such provenances which could be better adapted to changing growth environments. Stone pine has exceptionally low genetic diversity (Vendramin et al. 2008, Sánchez-Gómez et al. 2011) and adult trees show a higher phenotypic plasticity than adaptive differentiation between provenances in survival, phenology, growth, and ontogeny (Mutke et al. 2010). In this context, phenotypic plasticity is defined as the ability of a species to alter its morphology and physiology in response to changes in the environment (Chambel et al. 2007). However, we still need to clarify if it is possible to identify a differential performance among stone pine provenances in the regeneration phase and to determine if these possible differences respond to the trade-offs between light and soil water availability. Thus, we hypothesized that provenances from contrasting geographic origins would show phenotypic differentiation in functional traits and different phenotypic plasticity in response to the combined effect of shade and drought. If no differentiation is found, we would confirm the low level of diversity of the species, which is counteracted by its high adaptive phenotypic plasticity (Chambel et al. 2007; Sánchez-Gómez et al. 2011) that gives the species an adaptive advantage in the environmentally unpredictable Mediterranean ecosystems (Mutke et al. 2010).

years under standard growing conditions (forest pot containers with 50 individual $300-\mathrm{cm}^{3}$ cells, soil was a mixture of peat and vermiculite, plants were fertilized with a liquid fertilizer injection program). In March 2012, plants were transplanted to $3-\mathrm{L}$ pots filled with a mixture of peat and vermiculite $(3: 1, \mathrm{v} / \mathrm{v})$ and transferred to a greenhouse $\left(26.0^{\circ} \mathrm{C} \pm 2.4^{\circ} \mathrm{C}\right.$ day $/ 20.7^{\circ} \mathrm{C} \pm 1.4^{\circ} \mathrm{C}$ night, air humidity of $52 \pm 10 \%$, natural photoperiod), where they were grown for five months. Plants were kept at water field capacity before initiating the experiment.

After the acclimation period, 96 plants (24 plants per provenance) were selected and arranged in a split-plot 


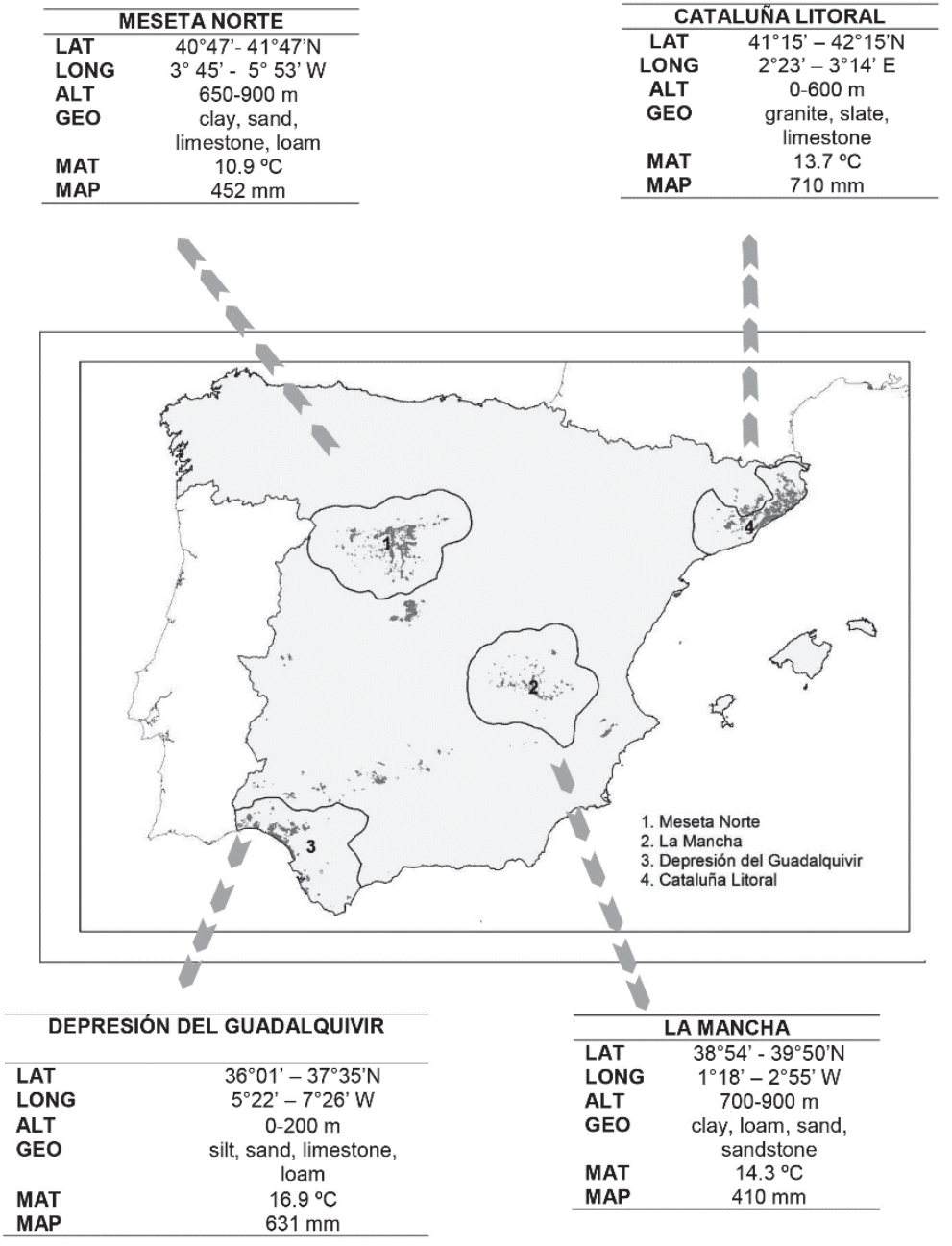

Fig. 1. Geographical location of the studied provenances (seed source) in Spain. Latitude (LAT), longitude (LONG), altitude (ALT), geology (GEO), mean annual temperature (MAT) and mean annual precipitation (MAP) corresponding to the geographical centre of the provenance. (Climate data source: Spanish Climate National Agency) experiment with three factors: light (two levels), water (two levels), and provenance (four levels), with treatments replicated in six blocks. Light factor consisted of two light environments: $100 \%(\mathrm{~L}+)$ and $40 \%(\mathrm{~L}-)$ of sunlight inside the greenhouse. The average PPFD under each light environment during a sunny day was $112.32 \mathrm{~mol}$ (photon) $\mathrm{m}^{-2}$ per $\mathrm{d}(\mathrm{L}+)$ and $44.06 \mathrm{~mol}$ (photon) $\mathrm{m}^{-2}$ per $\mathrm{d}(\mathrm{L}-$ ). These two light environments tried to mimic the effect of clear-cutting $(\mathrm{L}+)$ and a shelter-wood-cutting $(\mathrm{L}-)$ for Pinus pinea natural regeneration. Plants were grown under 12 open metal frames $(50 \times 80 \times 150 \mathrm{~cm}, 6$ blocks per each light environment), with capacity for eight plants (two per provenance). Six frames had no shade $(\mathrm{L}+)$ and the other six frames were covered with a neutral shade cloth to produce the $\mathrm{L}-$. Every $\mathrm{L}+/ \mathrm{L}-$ adjacent pair of frames conform a block. Plants growing within each frame were divided in two groups for the water treatment; thus, within each frame there was one plant per provenance $\times$ water regime combination. Plants were drip-irrigated individually. Volumetric water content (VWC) of the substrate was monitored twice per week using a portable timedomain reflectometer (TDR) equipped with three $16-\mathrm{cm}$ rod probes (TRIME FM 3, IMKO, Germany). Water content in the well-watered plants $(\mathrm{W}+)$ was maintained at $25 \%$, while the water-stressed plants $(\mathrm{W}-)$ were subjected to a moderate water stress by keeping water content at $10 \%$. Repeated measurement analysis of variance $(A N O V A)$ showed no significant differences $(p>0.05)$ in soil moisture between light levels. A continuous recording of air temperature and light was performed every $30 \mathrm{~min}$ using a $H O B O$ micro-weather station (Micro-HWS, ONSET, Massachusetts, USA) installed under both light environments.

Plant morphology and allometry: During the experimental period (from July 2012 to March 2013), plant height was measured in all the plants three times (July 2012, October 2012, and February 2013). Accumulated relative height growth (RHG) was calculated as $\mathrm{RHG}=$ $\left(\ln \mathrm{H}_{2}-\ln \mathrm{H}_{1}\right) /\left(\mathrm{t}_{2}-\mathrm{t}_{1}\right)$, where $\mathrm{H}_{2}$ and $\mathrm{H}_{1}$ represent the final and initial height and $t_{2}-t_{1}$ is the time elapsed between measurements.

Plants were harvested in February 2013 (64 plants, 16 plants per provenance). Seedlings were selected to attain a balanced sample of provenances and light $v s$. water availability treatments. Plants were washed carefully and 
divided into stems, roots, and leaves. After scanning the leaves with a high-resolution scanner (EPSON $10000 \mathrm{XL})$, the projected leaf area $\left(\mathrm{LA}, \mathrm{cm}^{2}\right)$ was estimated using the image analysis software Winrhizo (Regent Instruments Inc., Canada). Biomass of roots (RDM), stem (SDM), shoots (ShDM), leaves (LDM), and the whole plant (TDM) on a dry mass basis, were obtained after oven drying at $65^{\circ} \mathrm{C}$ for $48 \mathrm{~h}$. The following indices were then calculated: specific leaf area (SLA, leaf area/leaf mass, $\mathrm{m}^{2} \mathrm{~kg}^{-1}$ ), leaf mass fraction (LMF, leaf mass/plant mass, $\mathrm{g}^{-1}$ ), stem mass fraction (SMF, stem mass/plant mass, $\mathrm{g} \mathrm{g}^{-1}$ ), shoot mass fraction (ShMF, shoot mass/plant mass, $\mathrm{g} \mathrm{g}^{-1}$ ), root mass fraction (RMF, root mass/plant mass, $\left.\mathrm{g} \mathrm{g}^{-1}\right)$, and shoot to root ratio ( $\left.\mathrm{S} / \mathrm{R}, \mathrm{g} \mathrm{g}^{-1}\right)$.

Photosynthetic light-response curves: In February 2013, light-response curves were constructed for the 32 plants that were harvested afterwards. Curves were constructed by measuring net photosynthesis $\left(P_{\mathrm{N}}\right)$ at increasing values of PPFD with a portable infrared gas analyser (LCPro+, Analytical Development Corporation, UK). Temperature was set at $26 \pm 2^{\circ} \mathrm{C}$ and $\mathrm{CO}_{2}$ at $385-420 \mathrm{ppm}$. A 5-7-cm long branch per seedling was placed in the leaf chamber and illuminated with $1,500 \mu \mathrm{mol}$ (photon) $\mathrm{m}^{-2} \mathrm{~s}^{-1}$. The output of the diode array (blue LED at 470nm and red ones at $660 \mathrm{~nm}$ ) was monitored with a light sensor. The starting PPFD (I) was $1,500 \mu \mathrm{mol} \mathrm{m}{ }^{-2} \mathrm{~s}^{-1}$ followed by 1,$200 ; 1,100$; $800,600,400,200,100$, and $0 \mu \mathrm{mol} \mathrm{m} \mathrm{m}^{-2} \mathrm{~s}^{-1}$. At each PPFD, the measurements were taken when the photosynthetic rate reached steady state (after about $10 \mathrm{~min}$ ). The photosynthetic response to PPFD for each plant was modeled by a nonrectangular hyperbolic model of photosynthesis (Thornley and Johnson 1990), adapted for the species (see Calama et al. 2013 for details) (Eq. 1). In the model, net photosynthetic rate $\left(P_{\mathrm{N}}\right)$ is defined as the sum of dark respiration rate $\left(R_{\mathrm{D}}\right)$ and gross photosynthetic rate. Photosynthesis at zero PPFD corresponded to $R_{\mathrm{D}}$. The response of leaf gross photosynthetic rate to incident light (I) depends on three parameters: $P_{\text {gmax }}, \alpha$, and $\vartheta$.

$$
P_{\mathrm{N}}=R_{\mathrm{D}}+\frac{\alpha \mathrm{I}+P_{\text {gmax }}-\sqrt{\left(\alpha \mathrm{I}+P_{\text {gmax }}\right)^{2}-4 \vartheta \alpha \mathrm{I} P_{\text {gmax }}}}{2 \vartheta}
$$

where $P_{\text {gmax }}$, the upper asymptote of the light-response curve, is the maximum rate of gross photosynthesis at saturating irradiance; $\alpha$ is the initial slope of the lightresponse curve and the quantum yield of assimilation, which is related to the photochemical efficiency; $\vartheta$ is a dimensionless parameter linked to the carbon transport resistance, denotes the dimensionless convexity of the light-response curve.

Heat wave experiment: In March 2013, the remaining plants $(n=32)$ were used to mimic artificially the effect of a summer heat wave. Heat waves in the Mediterranean environment can be short, but intense, affecting negatively seedlings survival. Seedlings of the $\mathrm{W}$ - treatment $(n=16)$ were allowed to dry until they reached $3.2 \%$ of volumetric water content, which is a common value recorded during mid-summer in Pinus pinea stands. Then, the seedlings were transferred into a growth chamber for a week. The seedlings were kept at $25^{\circ} \mathrm{C}$ and light $/ 15^{\circ} \mathrm{C}$ at night, $60 \%$ humidity for five days, and then for two days at $33-35^{\circ} \mathrm{C}$, $30 \%$ humidity. The $\mathrm{W}-$ seedlings were allowed to dry from 3.2 to $1.2 \%$ in order to mimic field conditions, at the end of the week, while the $\mathrm{W}+$ seedlings were maintained at $25 \%$.

At the beginning and the end of the heat-wave experiment, chlorophyll (Chl) a fluorescence, gas-exchange parameters, and water status were measured on one 5-7-cm long branch of every seedling. A portable infrared gas analyser (LCPro+ Analytical Development Corporation, $\mathrm{UK})$ was used to measure net assimilation rate $\left(P_{\mathrm{N}}\right)$, stomatal conductance $\left(g_{\mathrm{s}}\right)$, and transpiration rate $(E)$. Gasexchange parameters were measured in the morning at a maximum irradiance light of $1,500 \mu \mathrm{mol}$ (photon) $\mathrm{m}^{-2} \mathrm{~s}^{-1}$. Photosynthesis values were expressed on a leaf area basis. Chl $a$ fluorescence was measured in the same twig with a portable pulse-modulated fluorometer (FMS 2, Hansatech Instruments Ltd., UK). Two sets of measurements were recorded, dark-adapted fluorescence (leaves were acclimated to dark for $30 \mathrm{~min}$ with dark-adaptation leaf clips) and morning light fluorescence. After measuring minimum fluorescence $\left(\mathrm{F}_{0}\right)$ in the dark-adapted leaf with $<0.05 \mu$ mol(photon) $\mathrm{m}^{-2} \mathrm{~s}^{-1}$, a 0.8 -s saturating pulse $[6,600$ $\mu \mathrm{mol}\left(\right.$ photon) $\mathrm{m}^{-2} \mathrm{~s}^{-1}$ ] was applied, and maximum fluorescence $\left(\mathrm{F}_{\mathrm{m}}\right)$ was measured to calculate maximum photochemical efficiency of PSII: $\left.F_{v} / F_{m}=\left(F_{m}-F_{0}\right) / F_{m}\right) . F_{v} / F_{m}$ was measured at predawn and in the morning. In the morning, immediately after measuring $\mathrm{F}_{\mathrm{v}} / \mathrm{F}_{\mathrm{m}}$, a halogen lamp (Osram 64255, $25 \mathrm{~W} / 8 \mathrm{~V}$ ) was turned on and a new saturating pulse applied $\left(\mathrm{F}_{\mathrm{m}}\right.$ ') after steady-state fluorescence $\left(\mathrm{F}_{\mathrm{s}}\right)$ was reached. The yield of photochemistry in PSII $\left(\Phi_{\text {PSII }}\right)$ was calculated as $\Phi_{\text {PSII }}=\left(F_{\mathrm{m}}{ }^{\prime}-F_{\mathrm{s}}\right) / F_{\mathrm{m}}$ ' and the apparent photosynthetic electron transport rate (ETR) was estimated as $\mathrm{ETR}=\Delta \mathrm{F} / \mathrm{F}_{\mathrm{m}}{ }^{\prime} \times \mathrm{PPFD} \times 0.84 \times 0.5$. Leaf temperature during the measuring period was $22.0 \pm 0.3^{\circ} \mathrm{C}$ at the beginning of the heat-wave experiment and $34.4 \pm$ $0.3^{\circ} \mathrm{C}$ at the end. Predawn water potential $\left(\psi_{\mathrm{pd}}, \mathrm{MPa}\right)$ was measured with a pressure chamber (PMS Instrument Co. 7000, Corvallis, Oregon).

Indices of plasticity: An index of phenotypic plasticity ranging from 0 to 1 was calculated for each variable and provenance as the difference between the maximum and the minimum mean values between the four treatment combinations $(\mathrm{L}+\mathrm{W}+, \mathrm{L}+\mathrm{W}-, \mathrm{L}-\mathrm{W}+$, and $\mathrm{L}-\mathrm{W}-$ ) divided by the maximum mean value (Valladares et al. 2000). A mean phenotypic plasticity was calculated for each trait and provenance, as well as an average phenotypic plasticity for morphological traits (growth and allometry), 
photosynthetic light-response curve traits, and physiological traits from the heat wave experiment. Mean plasticity before and after the heat wave was also considered.

Data analysis: To detect the effects of light, water availability, and provenance (as well as their interaction) on the different morphological variables analyzed, a threeway analysis of variance $(A N O V A)$ was performed. When the interaction was significant $(p \leq 0.05)$, one-way $A N O V A$ was used for each factor separately. Tukey's tests were performed for comparison of means. Residuals were checked for normality, homoscedasticity, and outlier detection. The physiological response traits observed before and after the heat-wave experiment were analyzed in a similar fashion.

For the photosynthetic light-response curves, the nonrectangular hyperbolic model (Eq. 1) was fitted separately for each plant, resulting in 32 independent photo-

\section{Results}

Shoot growth, plant morphology and allometry: All seedlings showed similar shoot height at the beginning of the experiment in July $2012(38.5 \pm 0.7 \mathrm{~cm})$. By October 2012 and again in February 2013, significant differences between provenances were recorded in shoot height (Fig. 2A). For instance, LM provenance grew $6.5 \mathrm{~cm}$ higher than that of DG by February 2013, related to a
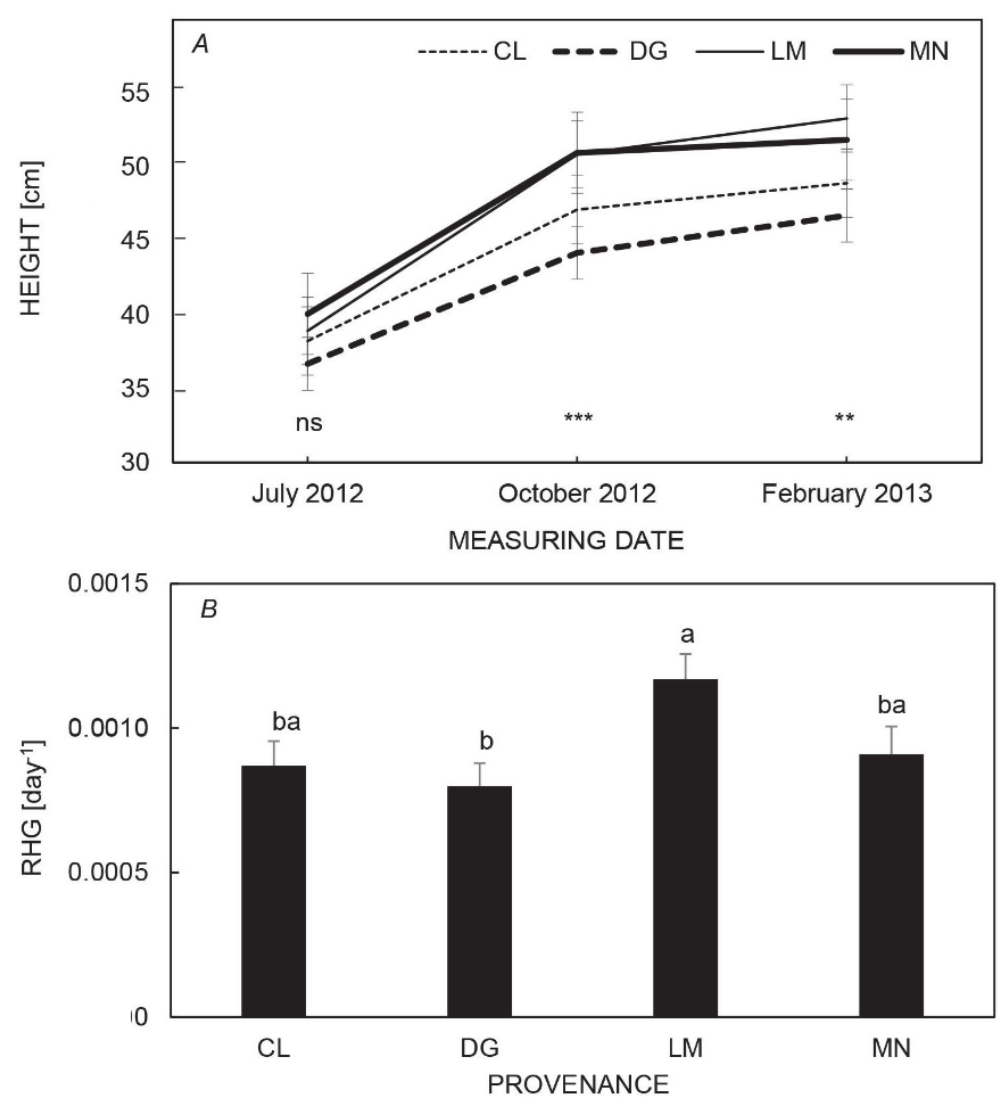

synthetic light curves. As a preliminary step, data from each moment of measurement were examined to remove outliers and measurement errors. The model fit was carried out through ordinary nonlinear least squares regression techniques and parameters $P_{\text {gmax }}$ and $\alpha$ were estimated for each plant, while parameter $\theta$ was given a fixed value of 0.55 (Calama et al. 2013). All the nonlinear regression analyses were made using procedure NLIN in $S A S \AA /$ $S T A T$ 9.2. A three-way $A N O V A$ was then performed to study the effect of provenance, light, and water treatments on $R_{\mathrm{D}}, P_{\mathrm{gmax}}$, and $\alpha . S A S \circledR$ statistical package (procedures GLM and NLIN) was used for the statistical analysis.

The effect of provenance on the plasticity indices was also analyzed by a one-way $A N O V A$. In order to analyze the effect of provenance and to explore the existence of internal trends, we conducted a principal components analysis of the phenotypic plasticity.

higher accumulated relative height growth RHG (Fig. 2B). The $\mathrm{W}+$ seedlings were significantly taller in October 2012, but the effect was no longer significant by February 2013. There was no light effect on shoot height or RHG over the experiment and the interactions were not significant. 
Table 1. ANOVA results ( $F$-statistic value and probability levels) of the effect of provenance, light, and water availability on morphological traits and allometry, light-response curves traits calculated through the nonrectangular hyperbolic model of photosynthesis, and physiological traits before and after the one-week simulated heat wave. Probability levels are indicated as $*-p \leq 0.05, * *-p \leq 0.01, * * *-p \leq 0.001, \mathrm{~ns}-p \geq 0.05$.

\begin{tabular}{|c|c|c|c|c|c|c|c|}
\hline & $\begin{array}{l}\text { Water } \\
\text { availability (W) }\end{array}$ & Light (L) & Provenance $(\mathrm{P})$ & $\mathrm{P} \times \mathrm{L}$ & $\mathrm{P} \times \mathrm{W}$ & $\mathrm{L} \times \mathrm{W}$ & $\mathrm{P} \times \mathrm{L} \times \mathrm{W}$ \\
\hline \multicolumn{8}{|l|}{ Morphology and allometry } \\
\hline $\mathrm{RDM}[\mathrm{g}]$ & $7.11^{* *}$ & $26.91^{* * *}$ & ns & ns & ns & $4.70^{*}$ & ns \\
\hline SDM [g] & ns & $6.04^{*}$ & ns & ns & ns & ns & ns \\
\hline LDM [g] & ns & ns & ns & ns & ns & ns & ns \\
\hline $\operatorname{ShDM}[\mathrm{g}]$ & ns & $9.17^{* *}$ & $3.84^{*}$ & ns & $2.76^{*}$ & ns & $4.64^{* *}$ \\
\hline TDM $[\mathrm{g}]$ & ns & $18.21^{* * *}$ & $3.34^{*}$ & ns & $3.26^{*}$ & ns & $3.69^{*}$ \\
\hline $\mathrm{LA}\left[\mathrm{cm}^{2}\right]$ & ns & ns & ns & ns & $\mathrm{ns}$ & ns & $\mathrm{ns}$ \\
\hline $\mathrm{S} / \mathrm{R}\left[\mathrm{g} \mathrm{g}^{-1}\right]$ & ns & $5.50^{*}$ & ns & ns & ns & ns & ns \\
\hline RMF [ $\left.\mathrm{g} \mathrm{g}^{-1}\right]$ & $7.72^{* *}$ & $15.20^{* *}$ & ns & ns & ns & ns & ns \\
\hline SMF $\left[\mathrm{g} \mathrm{g}^{-1}\right]$ & ns & ns & ns & ns & ns & ns & ns \\
\hline $\operatorname{LMF}\left[\mathrm{g} \mathrm{g}^{-1}\right]$ & ns & $4.34^{*}$ & ns & ns & ns & ns & ns \\
\hline ShMF $\left[\mathrm{g} \mathrm{g}^{-1}\right]$ & $7.71^{* *}$ & $15.20^{* *}$ & ns & ns & ns & ns & ns \\
\hline SLA $\left[\mathrm{m}^{2} \mathrm{~kg}^{-1}\right]$ & $\mathrm{ns}$ & ns & ns & ns & ns & ns & ns \\
\hline RHG $\left[\right.$ day $\left.^{-1}\right]$ & ns & ns & $3.70^{* *}$ & ns & ns & ns & ns \\
\hline \multicolumn{8}{|l|}{ Light-response curve traits } \\
\hline$R_{\mathrm{D}}\left[\mu \mathrm{mol}\left(\mathrm{CO}_{2}\right) \mathrm{m}^{-2} \mathrm{~s}^{-1}\right]$ & $108.01^{* * *}$ & $7.26^{*}$ & $3.62^{*}$ & ns & $3.03^{*}$ & ns & ns \\
\hline$P_{\operatorname{gmax}}\left[\mu \operatorname{mol}\left(\mathrm{CO}_{2}\right) \mathrm{m}^{-2} \mathrm{~s}^{-1}\right]$ & $6.27^{*}$ & $11.95^{* *}$ & $\mathrm{~ns}$ & ns & ns & $7.85^{*}$ & ns \\
\hline$\alpha\left[\mathrm{mol}\left(\mathrm{CO}_{2}\right) \mathrm{mol}^{-1}\right.$ (photon) $]$ & $12.48^{* *}$ & ns & ns & ns & ns & ns & ns \\
\hline \multicolumn{8}{|l|}{$\begin{array}{l}\text { Heat_wave } \\
\text { Before }\end{array}$} \\
\hline$P_{\mathrm{N}}\left[\mu \mathrm{mol}\left(\mathrm{CO}_{2}\right) \mathrm{m}^{-2} \mathrm{~s}^{-1}\right]$ & $38.91^{* * *}$ & ns & ns & ns & ns & ns & ns \\
\hline$E\left[\mathrm{mmol}\left(\mathrm{H}_{2} \mathrm{O}\right) \mathrm{m}^{-2} \mathrm{~s}^{-1}\right]$ & $8.88^{* *}$ & ns & ns & ns & ns & ns & ns \\
\hline$g_{\mathrm{s}}\left[\mathrm{mmol}\left(\mathrm{H}_{2} \mathrm{O}\right) \mathrm{m}^{-2} \mathrm{~s}^{-1}\right]$ & $22.05^{* * *}$ & $\mathrm{~ns}$ & ns & ns & ns & ns & ns \\
\hline $\mathrm{F}_{\mathrm{v}} / \mathrm{F}_{\mathrm{m}}$ & ns & $8.21^{*}$ & ns & ns & ns & ns & ns \\
\hline $\operatorname{ETR}\left[\mu \mathrm{mol}\left(\mathrm{e}^{-}\right) \mathrm{m}^{-2} \mathrm{~s}^{-1}\right]$ & $4.32 *$ & ns & ns & ns & ns & ns & ns \\
\hline ФPSII & $38.39^{* * *}$ & ns & ns & ns & ns & ns & ns \\
\hline \multicolumn{8}{|l|}{ After } \\
\hline$P_{\mathrm{N}}\left[\mu \mathrm{mol}\left(\mathrm{CO}_{2}\right) \mathrm{m}^{-2} \mathrm{~s}^{-1]}\right.$ & $86.76^{* * *}$ & ns & $3.70^{*}$ & ns & ns & ns & ns \\
\hline$E\left[\operatorname{mmol}\left(\mathrm{H}_{2} \mathrm{O}\right) \mathrm{m}^{-2} \mathrm{~s}^{-1}\right]$ & $18.44^{* *}$ & ns & ns & ns & ns & ns & ns \\
\hline$g_{\mathrm{s}}\left[\mathrm{mmol}\left(\mathrm{H}_{2} \mathrm{O}\right) \mathrm{m}^{-2} \mathrm{~s}^{-1}\right]$ & $16.54^{* * *}$ & ns & ns & ns & ns & ns & ns \\
\hline $\mathrm{F}_{\mathrm{v}} / \mathrm{F}_{\mathrm{m}}$ & $4.44^{* *}$ & $32.05^{* * *}$ & ns & ns & ns & ns & ns \\
\hline $\operatorname{ETR}\left[\mu \mathrm{mol}\left(\mathrm{e}^{-}\right) \mathrm{m}^{-2} \mathrm{~s}^{-1}\right]$ & $4.32 *$ & ns & ns & ns & ns & ns & ns \\
\hline$\Phi_{\text {PSII }}$ & $26.2^{* * *}$ & $10.96^{* *}$ & ns & ns & ns & ns & ns \\
\hline
\end{tabular}

Results from the harvest showed that biomass allocationrelated traits were mainly affected by light (total biomass and shoot, stem and root biomass, shoot to root ratio, RMF, $\mathrm{LMF}$, and ShMF), and to a lesser extent by provenance (shoot and total biomass), and water regime (root biomass, RMF and ShMF) (Table 1). Significantly higher values were found for seedlings that received high light, compared to low light, except shoot to root ratio which decreased with increasing light. Provenance LM showed a significantly higher shoot biomass and total biomass than DG (Fig. $3 A$ ). Significant interactions light $\times$ water regime (for $\mathrm{RDM}$ ), provenance $\times$ water regime (for $\mathrm{ShDM}$ and $\mathrm{TDM}$ ), and provenance $\times$ light $\times$ water (for $\mathrm{ShDM}$ and TDM) were found (Table 1). The inland provenances LM and MN showed a significantly higher ShDM and TDM under high light and high water availability $(\mathrm{L}+\mathrm{W}+)$ compared to the coastal provenances.

Average differences in ShMF and RMF with growing irradiance are shown in Fig. $3 B$. Average ShMF and LMF decreased with increasing irradiance in all harvests, whereas RMF increased in a very consistent manner. In the case of the water regime, on average, allocation changed shifted from shoot to root, although changes were not significant.

Photosynthetic light-response curves: Results from the photosynthetic light curves (Table 1, Fig. 4) showed a significant effect of the water regime (on $R_{\mathrm{D}}, P_{\mathrm{gmax}}$, and $\alpha$ ), 

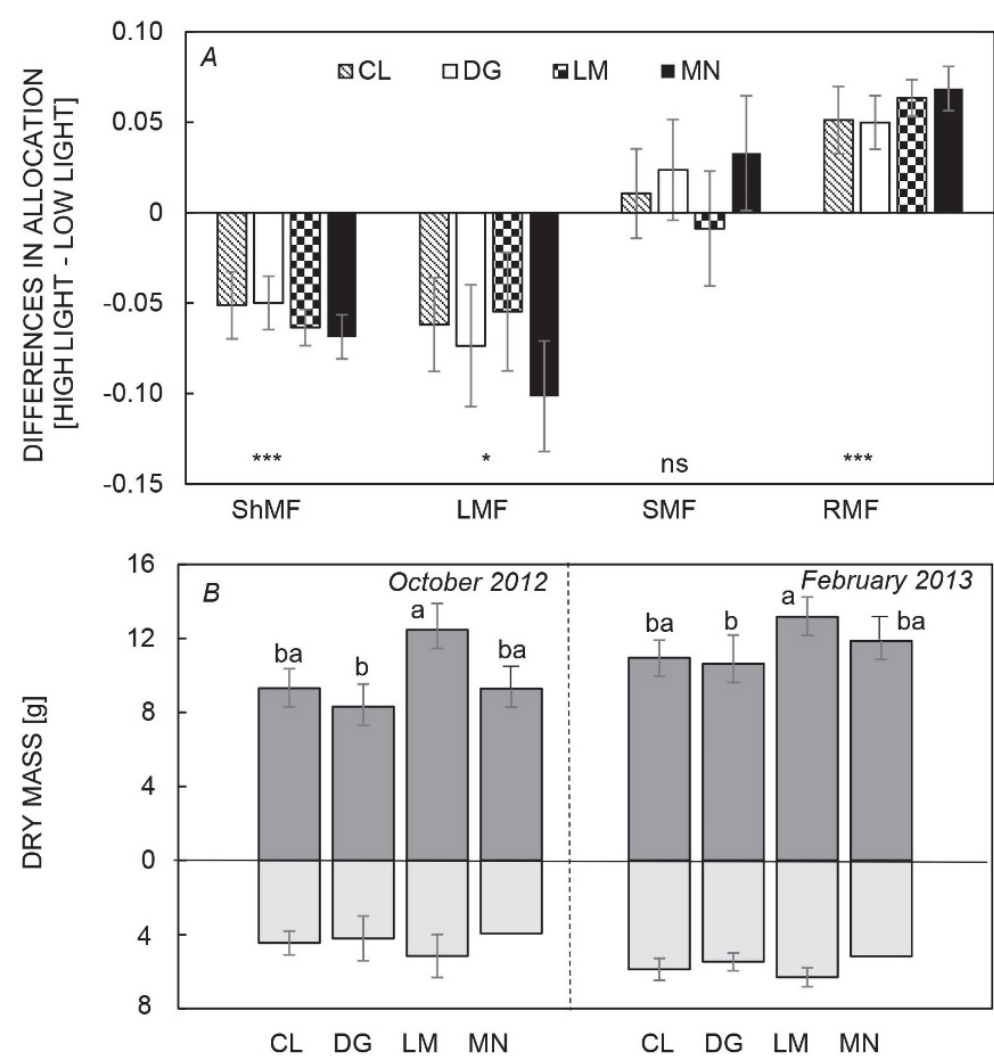

Fig. 3. (A) Differences in biomass allocation expressed as shoot mass fraction (ShMF), stem mass fraction (SMF), leaf mass fraction (LMF), and root mass fraction (RMF) between plants grown at a high and a low level of light (high resource availability low resource availability). Average values ( \pm SE) correspond to the pooled data of October 2012 and February 2013 harvests $(n=64)$. Asterisks indicate the significance level under the $\mathrm{H}_{0}$ hypothesis of no difference in allocation, combining the data for provenances. $*-p<0.05, * *-p<0.01, * * *-p<0.001$, ns - insignificant. (B) Shoot (dark grey) and root (light grey) dry mass for each provenance and harvest (October 2012 and February 2013). Different letters indicate significant differences between provenances within each harvest. Cataluña litoral (CL), Depresión del Guadalquivir (DG), La Mancha (LM), and Meseta Norte (MN). light (on $R_{\mathrm{D}}$ and $P_{\text {gmax }}$ ), provenance (on $R_{\mathrm{D}}$ ), and the provenance $\times$ water regime (on $R_{\mathrm{D}}$ ) and light $\times$ water regime (on $P_{\text {gmax }}$ ) interactions. The $\mathrm{W}$ - seedlings showed a significant decrease of $81 \%$ in $R_{\mathrm{D}}$, a decrease of $27 \%$ in $P_{\text {gmax }}$, and an increase of $33 \%$ in $\alpha$, compared to the $\mathrm{W}+$ seedlings (Table $1 \mathrm{~S}$ ). The effect of light also shifted $R_{\mathrm{D}}$ significantly, from $-1.24 \mu \mathrm{mol}\left(\mathrm{CO}_{2}\right) \mathrm{m}^{-2} \mathrm{~s}^{-1}$ under low light to $-1.56 \mu \mathrm{mol}\left(\mathrm{CO}_{2}\right) \mathrm{m}^{-2} \mathrm{~s}^{-1}$ under high light, while it increased $P_{\text {gmax }}$. The significant light $\times$ water regime interaction on $\mathrm{P}_{\text {gmax }}$ showed that the combined effect of L-W- significantly decreased $P_{\text {gmax }}$ (from a mean value of $8.48 \mu \mathrm{mol}\left(\mathrm{CO}_{2}\right) \mathrm{m}^{-2} \mathrm{~s}^{-1}$ in $\mathrm{L}+\mathrm{W}+, \mathrm{L}+\mathrm{W}-$, and $\mathrm{L}-\mathrm{W}+$ to $2.61 \mu \mathrm{mol}\left(\mathrm{CO}_{2}\right) \mathrm{m}^{-2} \mathrm{~s}^{-1}$ in $\left.\mathrm{L}-\mathrm{W}-\right)$. The $\mathrm{CL}$ provenance showed lower respiration rates $\left(R_{\mathrm{D}}\right.$ values of -1.10 $\left.\mu \mathrm{mol}\left(\mathrm{CO}_{2}\right) \mathrm{m}^{-2} \mathrm{~s}^{-1}\right)$ compared to DG and LM provenances $\left[R_{\mathrm{D}}\right.$ values of $\left.-1.60 \mu \mathrm{mol}\left(\mathrm{CO}_{2}\right) \mathrm{m}^{-2} \mathrm{~s}^{-1}\right]$. The significant provenance $\times$ water regime interaction on $R_{\mathrm{D}}$ showed that under $\mathrm{W}-$, DG provenance showed the higher respiration rates $\left[R_{\mathrm{D}}\right.$ value of $\left.-3.53 \mu \mathrm{mol}\left(\mathrm{CO}_{2}\right) \mathrm{m}^{-2} \mathrm{~s}^{-1}\right]$ compared to the other three provenances. Interestingly, $\mathrm{DG}$ provenance showed the highest $P_{\text {gmax }}$ under L+W+ [11.62 $\mu \operatorname{mol}\left(\mathrm{CO}_{2}\right)$ $\left.\mathrm{m}^{-2} \mathrm{~s}^{-1}\right]$, but the second lowest $P_{\operatorname{gmax}}\left[1.16 \mu \mathrm{mol}\left(\mathrm{CO}_{2}\right)\right.$ $\mathrm{m}^{-2} \mathrm{~s}^{-1}$ ] under L-W- (Fig. 4).

Summer heat-wave experiment: Increased water availability had a positive and significant effect on most measured variables at both dates (except $F_{v} / F_{m}$ before the heat wave), while the effect of high light was significant for the fluorescence variables (Table 1, Fig. 5). The effect of provenance was only significant after the heat wave. LM provenance showed a higher $P_{\mathrm{N}}\left[3.17 \mu \operatorname{mol}\left(\mathrm{CO}_{2}\right)\right.$ $\left.\mathrm{m}^{-2} \mathrm{~s}^{-1}\right]$ compared to $\mathrm{CL}$ provenance $\left[-0.81 \operatorname{mol}\left(\mathrm{CO}_{2}\right)\right.$ $\mathrm{m}^{-2} \mathrm{~s}^{-1}$ ] after the heat wave.

The heat wave decreased the value of all measured variables, except $E$. The decrease of $P_{\mathrm{N}}$ was dramatic [from 2.58 to $-3.11 \mu \mathrm{mol}\left(\mathrm{CO}_{2}\right) \mathrm{m}^{-2} \mathrm{~s}^{-1}$ ] and ETR [from 34.18 to $2.98 \mu \mathrm{mol}\left(\mathrm{e}^{-}\right) \mathrm{m}^{-2} \mathrm{~s}^{-1}$ ] in the $\mathrm{W}-$ seedlings. The $E$ increased to $130 \%$ in the $\mathrm{W}+$ seedlings during the heat wave, joined to a $50 \%$ increase in the $g_{s}$. The four provenances exhibited photoinhibition (values lower than 0.8 ), although they never dropped below 0.7 . The CL provenance reduced $P_{\mathrm{N}}$ the most during the heat wave [from 5.64 to $-0.81 \mu \mathrm{mol}\left(\mathrm{CO}_{2}\right) \mathrm{m}^{-2} \mathrm{~s}^{-1}$ ], while LM provenance decreased the least [from 5.51 to 3.17 $\mu \mathrm{mol}\left(\mathrm{CO}_{2}\right) \mathrm{m}^{-2} \mathrm{~s}^{-1}$.

Plasticity indices were significantly lower for morphological than those for physiological traits $(0.40 \pm 0.03$ for morphological parameters, $0.67 \pm 0.05$ for photosynthetic light-response curves parameters, and $0.48 \pm 0.06$ for physiological parameters from the heat-wave experiment). Variation in plasticity indices were greater for SLA, S/R, RDM, LDM, $P_{\mathrm{N}}, P_{\mathrm{gmax}}$, and $\alpha$ (Fig. 6); however, no significant differences between provenances were found in the plasticity indices. Nevertheless, regarding the mean plasticity index calculated for the photosynthetic lightresponse curves parameters, a strong trend towards higher values was found in $\mathrm{LM}$ and DG $(0.78 \pm 0.07)$ compared 
to $\mathrm{MN}$ and $\mathrm{CL}(0.55 \pm 0.11)$ provenances. Plasticity indices for all the physiological traits from the heat wave experiment were significantly higher after the heat wave, although no significant differences between provenances were found (Fig. 6). Multivariate comparisons between provenances for the phenotypic plasticity indices are

\section{Discussion}

Morphological response of the provenances to different light and water conditions: Various hypotheses have been proposed to explain the effects of drought on seedling performance along light gradients (e.g. Sack and Grubb 2002, Sack 2004). Our results provided contradictory evidence regarding the direction of the trade-off between shade and drought depending on the growth trait considered. As pointed out by Valladares et al. (2004), the literature on the possible interactions and trade-offs between shade and drought do not draw any general conclusions since they depend on the species-phenotype combination. According to the intraspecific hypothesis of a trade-off between shade tolerance and drought tolerance, dry soil should have a stronger impact on shoot growth under shade (Sack 2004) because of conflicts between simultaneous demands for allocation of resources to cope with above- and belowground limitations (SánchezGómez et al. 2006). This study did not support such a trade-off for shoot growth, i.e. the effects of shade and drought on shoot growth were orthogonal for the four provenances.

There is ample evidence that populations within a species often differ in phenotypic characters and genetic structure when experiencing different environmental conditions (Linhart and Grant 1996). Differences in genotype and phenotype interact with environmental factors such that their performance can vary among populations as a function of local adaptation and environment (Valladares et al. 2014). Although Pinus pinea shows an exceptional low level of genetic diversity, provenance tests involving material from across the range have revealed some differences in other adaptive traits (Vendramin et al. 2008). Our results showed generally similar shoot growth responses to varying water and light environments in the four studied provenances with contrasting ecological features. However, irrespective of the water and light environments, LM provenance (inland provenance) showed higher shoot growth, shoot biomass, and total biomass compared to DG provenance (southern coastal provenance). Such a contrast between inland and coastal provenances has been found in adult trees of different $P$. pinea provenances, inland provenances growing somewhat more vigorously (Court-Picon et al. 2004, Mutke et al. 2010).

Clearly, plants in general are hugely plastic in their partitioning towards roots, shoots, and foliage, resulting in differences in shoot to root ratios as an adaptation to site shown in Fig. 7. Factor loadings revealed a high phenotypic plasticity in $\mathrm{MN}$ provenance for most morphological traits. Regarding the photosynthetic lightresponse curves parameters, LM provenance showed high phenotypic plasticity for $P_{\mathrm{gmax}}, P_{\mathrm{N}}$, and $\alpha$, but low for $R_{\mathrm{D}}$. $P_{\mathrm{N}}$ and $g_{\mathrm{s}}$ changed the plasticity after the heat wave.

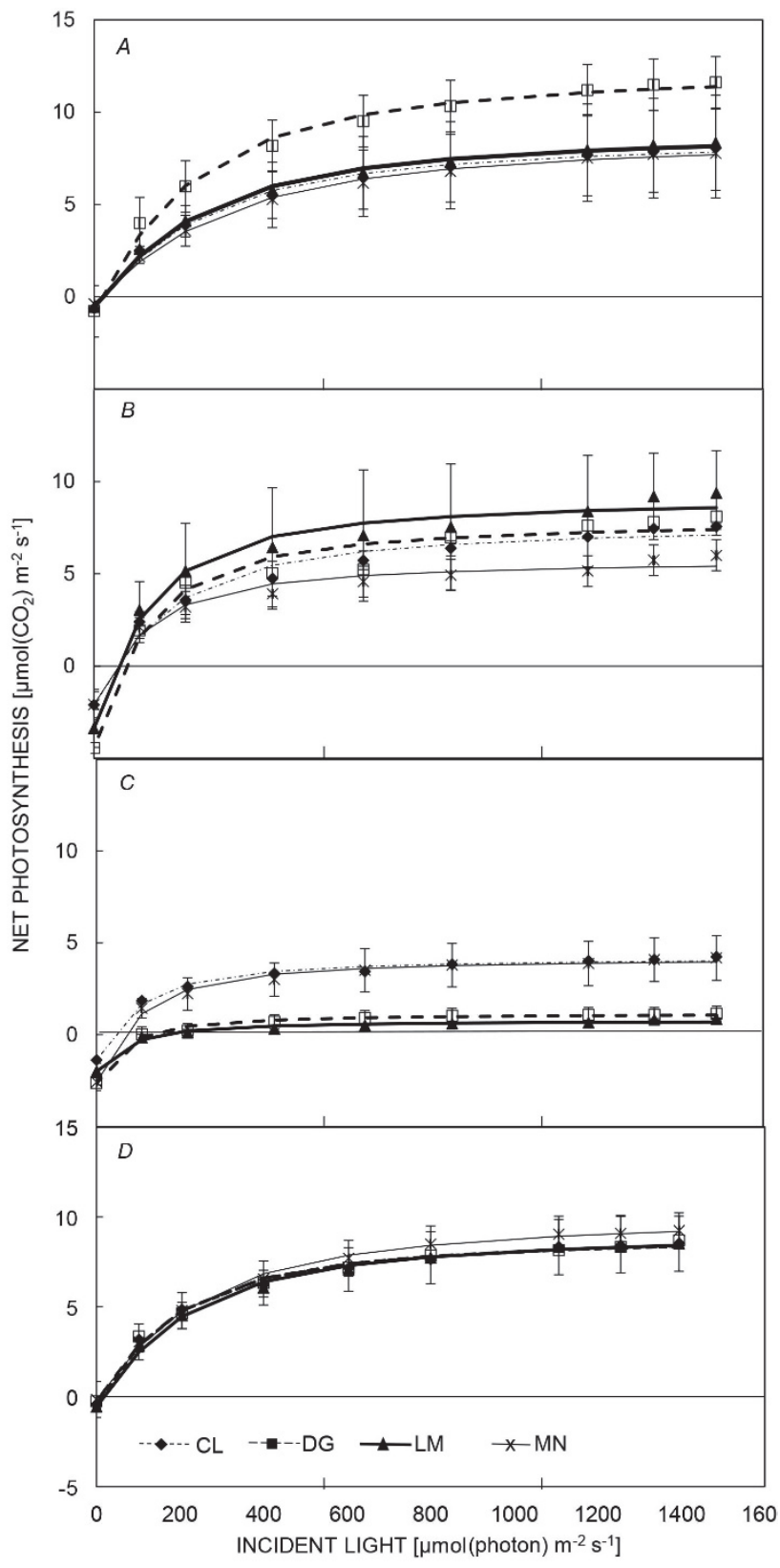

Fig. 4. Photosynthetic light-response curves for each treatment (light, water availability, and provenance) combination: $(A)$ $\mathrm{L}+/ \mathrm{W}+,(B) \mathrm{L}+\mathrm{W}-,(C) \mathrm{L}-\mathrm{W}-$, and $(D) \mathrm{L}-\mathrm{W}+$. Points represent mean measured values $(n=3)$; lines represent adjusted curves. Standard errors are shown. 


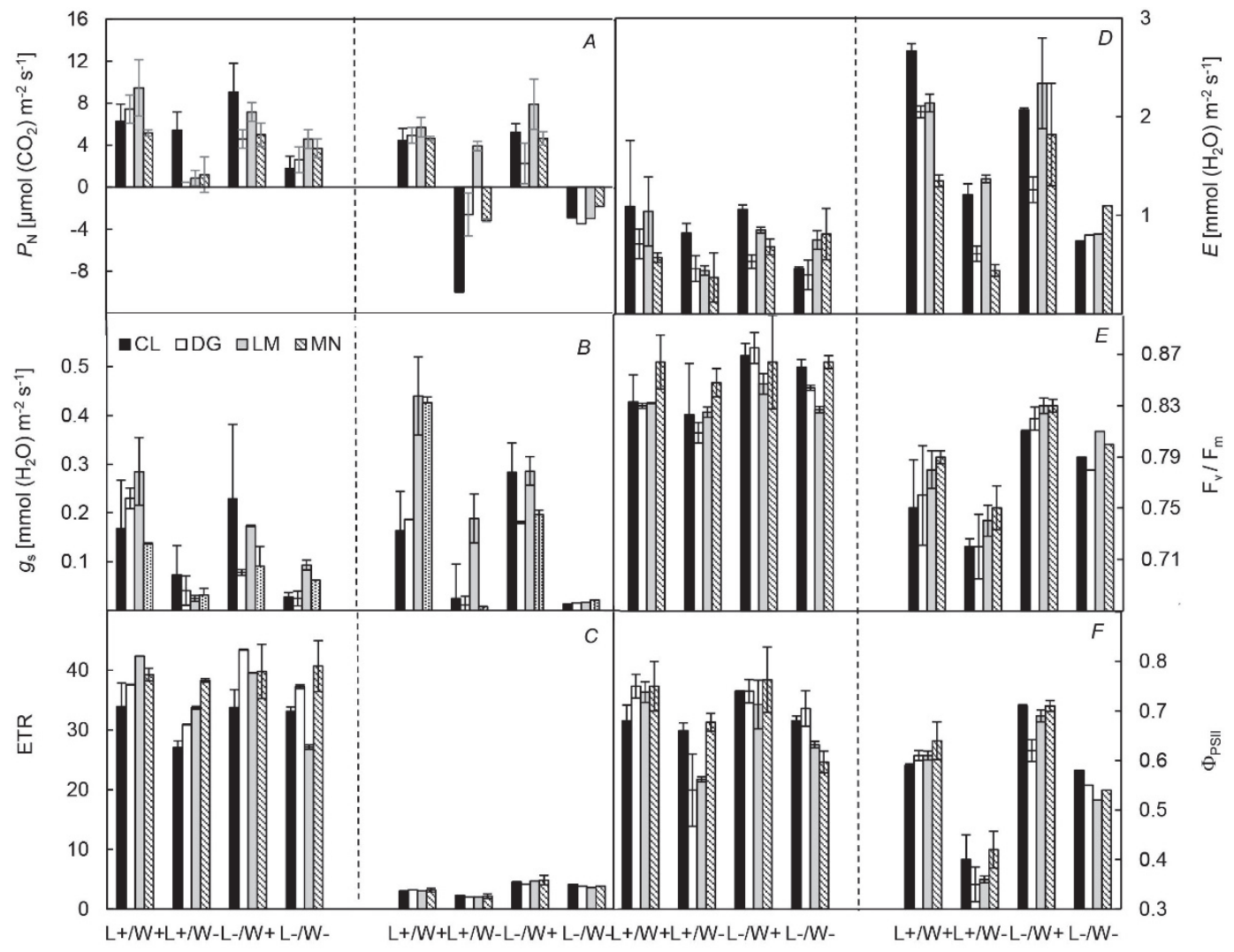

Fig. 5. Mean physiological parameters for each treatment combination before (left panels) and after (right panels) the one-week simulated heat wave $(n=32)$. ANOVA results $(F$-statistic value and probability levels $)$ of the effect of provenance, light, and water availability are shown, when significant. $P_{\mathrm{N}}-$ net assimilation rate; $E$ - transpiration rate; $g_{\mathrm{s}}-$ stomatal conductance; $\mathrm{F}_{\mathrm{v}} / \mathrm{F}_{\mathrm{m}}-$ maximum photochemical efficiency of PSII; ETR - apparent photosynthetic electron transport rate; ФPSII - yield of photochemistry in PSII.

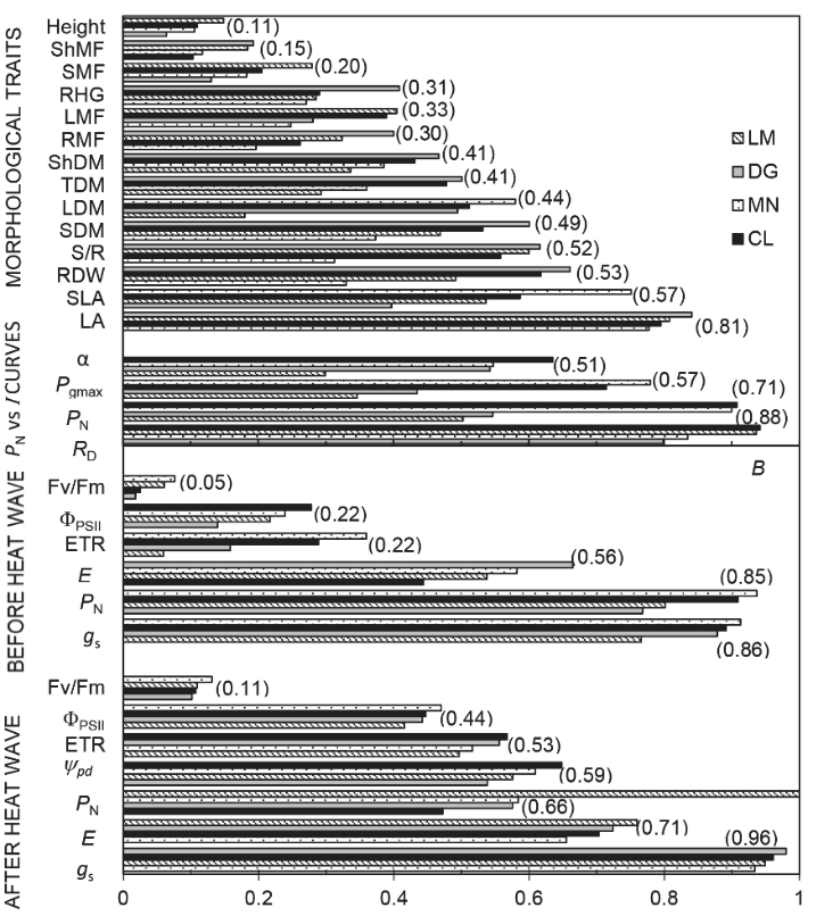

Fig. 6. Phenotypic plasticity index (maximum - minimum)/ maximum, for the four Pinus pinea provenances, for $(A)$ each of the 14 morphological traits (height, ShMF, SMF, RHG, LMF, RMF, ShDM, TDM, LDM, SDM, S/R, RDM, SLA, LA) ( $n=96)$, and 4 physiological variables derived from the photosynthetic light-response curves $\left(\alpha, P_{\operatorname{gmax}}, P_{\mathrm{N}}\right.$, and $\left.R_{\mathrm{D}}\right)(n=32)$ and $(B)$ the physiological traits measured before $\left(6\right.$ traits: $\mathrm{F}_{\mathrm{v}} / \mathrm{F}_{\mathrm{m}}, \Phi_{\mathrm{PSII}}$, ETR, $\left.E, P_{\mathrm{N}}, g_{\mathrm{s}}\right)$ and after $\left(7\right.$ traits: $\left.\mathrm{F}_{\mathrm{v}} / \mathrm{F}_{\mathrm{m}}, \Phi_{\mathrm{PSII}}, \mathrm{ETR}, E, P_{\mathrm{N}}, g_{\mathrm{s}}, \psi_{\mathrm{pd}}\right)$ the the one-week simulated heat wave $(n=32)$. Graphs within the figure and provenance within each graph are ordered by mean phenotypic plasticity. Mean phenotypic plasticity is shown in parenthesis.

conditions (Wolf et al. 2011). Light is the treatment that mostly affected the morphology and allometry of seedlings, affecting the four studied provenances in a similar way. The general form of the response of morphological traits and allometry to light was similar to what has been reviewed for other species (Poorter 1999, Poorter et al. 2012), that is, an increase in total biomass and biomass allocated to shoots, stem, and roots under high light. Average ShMF and LMF decreased and RMF increased with increasing light. Following the model of the functional equilibrium when plants preferentially allocate biomass to the organ that acquires the limiting resource 


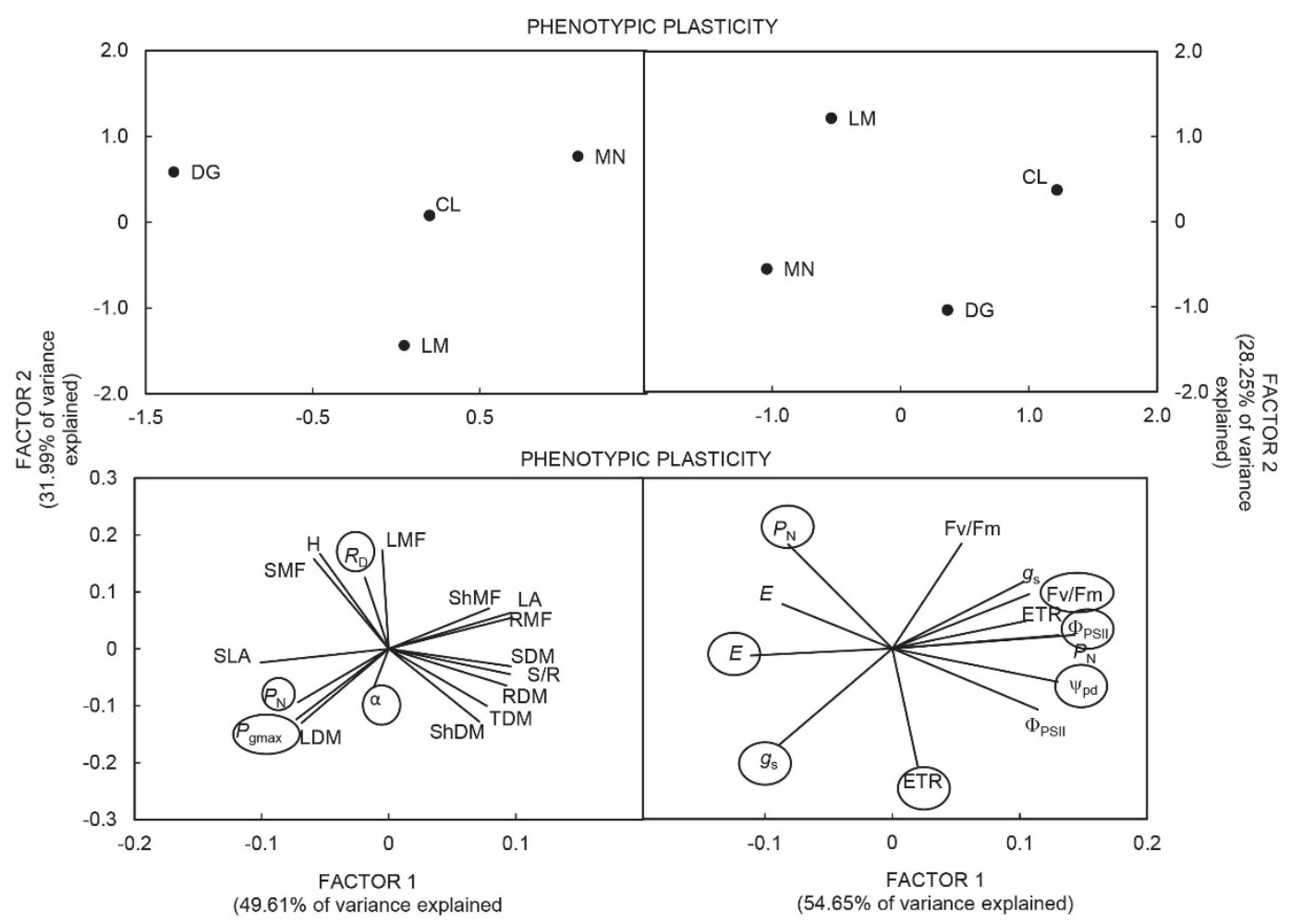

Fig. 7. Principal components ordination of the four Pinus pinea provenances (upper graphs) according to their phenotypic plasticity for the 14 morphological traits $(n=96)$ and the 4 physiological variables derived from the photosynthesis light-response curves $(n=32)$ (left) and for the 6-7 physiological traits measured during the 1-week simulated heat wave $(n=32)$ (right). Lower graphs show factor loadings. Open circles indicate the four physiological variables derived from the photosynthesis light-response curves (left) and the seven physiological traits measured after the one-week simulated heat wave (right).

(Brouwer 1983), seedlings grown at high light showed a shift of allocation from the leaves to the roots. The observed shoot to root ratio agreed with these predictions. However, seedlings grown under low water availability did not increase the allocation to roots as it was anticipated (e.g. Reich 2002).

Reich et al. (2014) suggested that perhaps the timescale of the water shortage is shorter than the plant's ability to shift its allocation strategy, thus limiting the efficacy of a partitioning strategy. In any case, our results were not surprising since the response seemed to depend on the drought intensity. For instance, several studies showed that plants subjected to moderate water stress (as is our case) showed a modest increase in RMF (e.g. Poorter and Nagel 2000). Although all plants reduced their root biomass (RMF) with decreasing light availability, the decrease was more obvious (approximately 50\%) under shade and drought conditions $(\mathrm{L}-\mathrm{W}-)$. Such smaller allocation of resources to the roots would limit water absorption and could have important implications in Mediterranean environments (Valladares and Pearcy 2002), irrespective of the provenance. On the contrary, the combination of shade and drought affected provenances' total biomass and the allocation to shoots differently. High availability of resources $(\mathrm{L}+\mathrm{W}+)$ clearly improved plant morphology of the two inland provenances (LM and $\mathrm{MN}$ ) whose total biomass and allocation to shoots was more negatively affected by shade than by low water availability, thus showing a poorer acclimation to shade conditions than that of the coastal provenances.

Physiological performance of the provenances: The analysis of the parameters from the photosynthetic light curves showed high sensitivity to water availability, medium to light, and low to provenance. When water availability decreased to $10 \%(\mathrm{~W}-)$, plants strongly decreased dark respiration $\left(R_{\mathrm{D}}\right)$, and the rate of gross photosynthesis at saturating light $\left(P_{\text {gmax }}\right)$ to a lesser extent, while $\alpha$ increased. Dark respiration is a clear pivotal determinant of net carbon balance in environments that constrain variation in photosynthesis (Sims et al. 1994). Additionally, the effect of shaded conditions ( $\mathrm{L}-$ ) mainly affected $P_{\text {gmax }}$. We also observed for $P_{\text {gmax }}$ that the response to a low water availability depended on the light environment, as the combined effect of low water availability and shade ( $\mathrm{W}-\mathrm{L}-$ ) was negatively additive for $P_{\text {gmax }}$, decreasing it by $69 \%$ in average. This suggests that under drier conditions the seedlings growing under shade conditions reduced $P_{\text {gmax }}$. The modelling of $P_{\text {gmax }}$ for Pinus pinea has shown that optimal conditions are located under mid-shaded environments that prevent carbon assimilation shortage due to shade and the combination of high water 
pressure deficit and photoinhibition under full light (Calama et al. 2013).

The response of the provenances to $R_{\mathrm{D}}$ was clear and followed a latitudinal range. Thus, the two provenances on the same latitudinal range, although with contrasting environmental conditions (i.e., the southern coastal provenance DG and the inland provenance LM) showed the lowest $R_{\mathrm{D}}$. Interestingly, provenances responded differently to water availability when considering $R_{\mathrm{D}}$. Although the four provenances decreased $R_{\mathrm{D}}$ under low water availability, the decrease in the southern coastal provenance DG was especially significant. The relatively higher respiration rate in the southern coastal provenance DG under low water availability might reflect its preferential allocation of photoassimilates to meristematic activity instead of to carbohydrate storage (Kaelke et al. 2001). In addition, the combination of low water availability and shade affected most negatively $P_{\text {gmax }}$ in DG provenance that, however, showed one of the highest $P_{\text {gmax }}$ under high resources availability $(\mathrm{L}+\mathrm{W}+)$. These results agreed with a higher plasticity index (although not significantly different) shown by this provenance.

None of the provenances exhibited photoinhibition before the heat wave, and reflected a high photosynthetic capacity in full sunlight, suggesting the low sensitivity of evergreen species, particularly of pine species, to high irradiances (Keeley and Zedler 1998, Gómez-Aparicio et al. 2006). As expected, the heat wave (that tried to mimic a heat wave during summer conditions under Mediterranean conditions) affected negatively all measured variables in the four provenances because of the concurrence of high temperatures and very low water availability (Calama et al. 2013), while the plasticity indices increased. Such increase in the plasticity is consistent with trends reported for mid-successional species such as stone pine (Awada et al. 2003). Similar to the results obtained for the morphological traits, the responses to varying water and light environments were similar for the four provenances, thus predicting an orthogonal effect of shade and drought (Sack 2004). After the heat wave, the $P_{\mathrm{N}}$ and ETR decreased dramatically, joined to a decrease in predawn water potential, because of photoinhibition, while the $E$ increased in a consistent manner. Such decreases that resulted in photoinhibition reduced the capacity of the four provenances to maximize photosynthetic utilization of light (Gatti and Rossi 2010). For instance, Pinus pinea has been reported to experience a significant depression in the photosynthetic capacity in response to hot summer days (Awada et al. 2003), together with stomata closure, coinciding with air temperatures as high as $35^{\circ} \mathrm{C}$ and with leaf water potentials around-2.0MPa (Manes et al. 1997). The species is especially sensitive to high temperatures and shows permanent damage to the photosynthetic apparatus for temperatures over $44^{\circ} \mathrm{C}$ (Rubio-Casal et al. 2010). In our study, the recovery of PSII at predawn (values of $\mathrm{F}_{\mathrm{v}} / \mathrm{F}_{\mathrm{m}}$ at predawn of 0.8 , data not shown) suggests that the water stress endured by the heat wave was within the range where midday photoinhibition remained largely reversible (Robson et al. 2008).

However, the photosynthetic response of the four provenances to the heat wave was not the same. Although the four provenances decreased $P_{\mathrm{N}}$, the decrease in LM provenance was not as sharp as in CL provenance. The differences in $P_{\mathrm{N}}$ between LM provenance and CL provenance were even more obvious when net photosynthesis was expressed per unit of dry mass [19.69 $\left.\mu \mathrm{mol}\left(\mathrm{CO}_{2}\right) \mathrm{g}^{-1}(\mathrm{DM}) \mathrm{s}^{-1} v s .-2.85 \mu \mathrm{mol}\left(\mathrm{CO}_{2}\right) \mathrm{g}^{-1}(\mathrm{DM}) \mathrm{s}^{-1}\right]$. Interestingly, $\mathrm{LM}$ provenance was able to maintain the highest $P_{\mathrm{N}}$ after the heat wave associated to (1) a slightly slower decrease in $\mathrm{F}_{\mathrm{v}} / \mathrm{F}_{\mathrm{m}}(0.79$ in the inland provenances $v s$. 0.77 in the coastal provenances), suggesting a more efficient photoinhibition defence mechanism in LM provenance during the heat wave; and (2) a higher accumulated relative height growth (RHG) in this inland provenance. As reported by Pons and Poorter (2014) photosynthesis increased proportionally with the growth rate.

Conclusion: Our results showed that despite the weak genetic polymorphism recorded for Pinus pinea, we found some differentiation in adaptive traits between the four studied provenances that cover the entire range of the species in Spain. Such differences are in accordance with the ecological grouping of the provenances along a latitudinal gradient and an inland vs. coastal gradient previously reported for adult trees in this species (Mutke et al. 2010), and for other pine species (Chuine et al. 2006, López et al. 2007). Particularly, the inland provenance La Mancha showed a higher morphological and physiological performance under both light and water availability environments that was also evident after the heat wave; thus, conferring an adaptive advantage compared to the other provenances. The differential performance of $\mathrm{La}$ Mancha provenance could be related to the particular climatic conditions of the provenance (the driest conditions but higher mean temperature). Two pending issues will be to (1) increase the sampling size in future experiments, and (2) set up a long-term study with the same provenances to confirm or reject our results during the adult phase.

Despite of the lack of differentiation in the phenotypic plasticity between provenances (also reported by Chambel et al. 2007), the high phenotypic plasticity shown in the four provenances reinforces the high adaptive plasticity of Pinus pinea that is able to adapt to a broad range of environments as an alternative to plant evolution. Such plasticity constitutes an advantage of the species to survive and perform in the unpredictable environment of the Mediterranean region, buffering climate change effects. This knowledge may help forest managers to choose the most suitable provenances able to cope better with climate change. 


\section{References}

Awada T., Radoglou K., Fotelli M.A. et al.: Ecophysiology of seedlings of three Mediterranean pine species in contrasting light regimes. - Tree Physiol. 23: 33-41, 2003.

Brouwer R.: Functional equilibrium: sense or nonsense? - Neth. J. Agric. Sci. 31: 335-348, 1983

Calama R., Puértolas J., Madrigal G. et al.: Modeling the environmental response of leaf net photosynthesis in Pinus pinea L. natural regeneration. - Ecol. Model. 251: 9-21, 2013

Chambel M.R., Climent J., Alía R.: Divergence among species and populations of Mediterranean pines in biomass allocation of seedlings grown under two watering regimes. - Ann. For. Sci. 64: 97-97, 2007.

Chuine I., Rehfeldt G.E., Aitken S.N.: Height growth determinants and adaptation to temperature in pines: a case study of Pinus contorta and Pinus monticola. - Can. J. Forest Res. 36: 1059-1066, 2006.

Court-Picon M.C., Gadbin-Henry C., Guibal F. et al.: Dendrometry and morphometry of Pinus pinea L. in Lower Provence (France): adaptability and variability of provenances. - Forest Ecol. Manag. 194: 319-333, 2004.

Cuesta B., Villar-Salvador P., Puértolas J. et al.: Facilitation of Quercus ilex in Mediterranean shrubland is explained by both direct and indirect interactions mediated by herbs. - J. Ecol. 98: 687-696, 2010.

D'Amato A.W., Bradford J., Fraver S., Palik B.: Forest management for mitigation and adaptation to climate change mitigation: insights from long-term silviculture experiments. Forest Ecol. Manag. 262: 803-816, 2011.

Demmig-Adams B., Adams W.W.: Photoprotection and other responses of plants to high light stress. - Annu. Rev. Plant Phys. 43: 599-626, 1992.

Gardiner E.S., Hodges J.D.: Growth and biomass distribution of cherrybark oak (Quercus pagoda Raf.) seedlings as influenced by light availability. - Forest Ecol. Manag. 108: 127-134, 1998.

Gatti E, Rossi F.: Daily and seasonal trends of gas exchange in Pistacia lentiscus L. - Acta Physiol. Plant. 32: 809-813, 2010.

Gómez-Aparicio L., Valladares F., Zamora R.: Differential light responses of Mediterranean tree samplings: linking ecophysiology with regeneration niche in four co-occurring species. - Tree Physiol. 26: 947-958, 2006.

Gordo F.J., Rojo L.I., Calama R. et al.: Silviculture of Pinus pinea L. natural regeneration in public forests in Valladolid province. - In: Gordo J., Calama R., M. Pardos et al. (ed.): [Natural Regeneration of Pine Stands in the Sandy Lands of the Spanish Northern Plateau.] Pp 145-160. Universidad de Valladolid-INIA, Valladolid 2012. [In Spanish]

Kaelke C.M., Kruger E.L., Reich P.B.: Trade-offs in seedling survival, growth, and physiology among hardwood species of contrasting successional status along a light-availability gradient. - Can. J. Forest Res. 31: 1602-1616, 2001.

Keeley J.E., Zedler P.H.: Evolution of life histories in Pinus. In: Richardson D.M. (ed.): Ecology and Biogeography of Pinus. Pp. 219-249. Cambridge University Press, Cambridge 1998.

Lindner M, Calama R.: Climate change and the need for adaptation in Mediterranean forests. - In: Lucas-Borja N.E. (ed.): Forest Management of Mediterranean Forests under the new Context of Climate Change. Building Alternatives for the Coming Future. Pp. 13-30. Nova Science Publ., New York 2013.

Lindner M., García J., Kolström M. et al.: Impacts of climate change on European forests and options for adaptation. Report to the EC Directorate-General for Agriculture and Rural Development, AGRI-2007-G4-06. Pp. 173. European Commission Directorate General for Agriculture and Rural Development, Brussels 2008.

Lindner M., Maroschek M., Netherer S. et al.: Climate change impacts, adaptive capacity, and vulnerability of European forest ecosystems. - Forest Ecol. Manag. 259: 698-709, 2010.

Linhart Y.C., Grant M.B.: Evolutionary significance of local genetic differentiation in plants. - Annu. Rev. Ecol. Syst. 27: 237-277, 1996.

Loewe-Muñoz V., Delard-Rodríguez C., Balzarini M. et al.: Impact of climate and management variables on stone pine (Pinus pinea L.) growing in Chile. - Agr. Forest Meteorol. 214215: 106-116, 2015.

López R., Zehavi A., Climent J. et al.: Contrasting ecotypic differentiation for growth and survival in Pinus canariensis. Aust. J. Bot. 55: 759-769, 2007.

Manes F., Seufert G., Vitale M.: Ecophysiological studies of Mediterranean plant species at the Castelporziano estate. Atmos. Environ. 31: 51-60, 1997.

Manso R., Pukkala T., Pardos M. et al.: Modelling Pinus pinea forest management to attain natural regeneration under present and future climatic scenarios. - Can. J. Forest Res. 44: 250262, 2014.

Mayoral C., Calama R., Sanchez-Gonzalez M. et al.: Modelling the influence of light, water and temperature on photosynthesis in young trees of mixed Mediterranean Forests. - New Forest. 46: 485-506, 2015.

Mutke S., Gordo J., Chambel M.R. et al.: Phenotypic plasticity is stronger than adaptative differentiation among Mediterranean Stone pine provenances. - For. Syst. 19: 356-366, 2010.

Pardos M., Climent J., Almeida H. et al:: The role of developmental stage in frost tolerance of Pinus pinea L. seedlings and saplings. - Ann. Forest Sci. 71: 551-562, 2014.

Pardos M., Puértolas J., Madrigal G. et al.: Seasonal changes in the physiological activity of regeneration under a natural light gradient in a Pinus pinea regular stand. - For. Syst. 19: 367380, 2010.

Pons T.L., Poorter H.: The effect of irradiance on the carbon balance and tissue characteristics of five herbaceous species differing in shade-tolerance. - Front. Plant Sci. 5: 1-14, 2014.

Poorter H., Nagel O.: The role of biomass allocation in the growth response of plants to different levels of light, $\mathrm{CO}_{2}$, nutrients and water: a quantitative review. - Aust. J. Plant Phys. 2: 595-607, 2000.

Poorter H., Niklas K.J., Reich P.B. et al.: Biomass allocation to leaves, stems and roots: meta-analyses of interspecific variation and environmental control. - New Phytol. 193: 3050, 2012.

Poorter L.: Growth responses of 15 rain-forest tree species to a light gradient: the relative importance of morphological and physiological traits. - Funct. Ecol. 13: 396-410, 1999.

Puértolas J., Oliet J.A., Jacobs D.F. et al.: Is light the key factor for success of tube shelters in forest restoration planting under Mediterranean climates. - Forest Ecol. Manag. 260: 610-617, 2010.

Reich P.B., Luo Y., Bradford J.B. et al.: Temperature drives global patterns in forest biomass distribution in leaves, stems, and roots. - P. Natl. Acad. Sci. USA 111: 13721-13726, 2014.

Reich P.B.: Root-shoot relations: optimality in acclimation and 
adaptation or the "Emperor's New Clothes". - In: Elshe A.K. (ed.): Plant Roots: the Hidden Half. Pp. 205-220. Wailey, New York 2002.

Robson T.M., Rodríguez-Calcerrada J., Sánchez-Gómez D. et al.: Summer drought impedes beech seedling performance more in a sub-Mediterranean forest understory than in small gaps. - Tree Physiol. 29: 249-259, 2009.

Rubio-Casal A.E., Leira-Doce P., Figueroa M.E. et al.: Contrasted tolerance to low and high temperatures of three tree taxa co-occurring on coastal dune forests under Mediterranean climate. - J. Arid Environ. 74: 429-439, 2010.

Sabaté S., Gracia C.A., Sánchez C.A.: Likely effects of climate change on growth of Quercus ilex, Pinus halepensis, Pinus pinaster, Pinus sylvestris and Fagus sylvatica forests in the Mediterranean region. - Forest Ecol. Manag. 162: 23-37, 2002.

Sack L., Grubb P.J.: The combined impacts of deep shade and drought on the growth and biomass allocation of shade-tolerant woody seedlings. - Oecologia 131: 175-185, 2002.

Sack L.: Responses of temperate woody seedlings to shade and drought: do trade-offs limit potential niche differentiation? Oikos 107: 107-127, 2004.

Sánchez-Gómez D., Valladares F., Zavala M.A.: Performance of seedlings of Mediterranean woody species under experimental gradients of irradiance and water availability: trade-offs and evidence for niche differentiation. - New Phytol. 170: 795-806, 2006.

Sánchez-Gómez D., Velasco-Conde T., Cano-Martín F.J. et al.: Inter-clonal variation in functional traits in response to drought for a genetically homogeneous Mediterranean conifer. Environ. Exp. Bot. 70: 104-109, 2011.

Sims D.A., Gebauer R.L.E., Pearcy R.W.: Scaling sun and shade photosynthetic acclimation of Alocasia macrorrhiza to whole- plant performance. - Plant Cell. Environ. 17: 889-900, 1994.

Spathelf P., van der Maaten E., van der Maaten-Theunissen et al.: Climate change impacts in European forests: The expert views of local observers. - Ann. Forest Sci. 71: 131-137, 2014.

Thornley J.H.M., Johnson I.R.: Plant and Crop Modeling: a Mathematical Approach to Plant and Crop Physiology. Pp. 73. The Blackburn Press, Caldwell 1990.

Valladares F., Dobarro I., Sánchez-Gómez D. et al.: Photoinhibition and drought in Mediterranean woody saplings: scaling effects and interaction in sun and shade phenotypes. J. Exp. Bot. 56: 483-494, 2005.

Valladares F., Matesanz S., Guilhaumon F. et al.: The effects of phenotypic plasticity and local adaptation on forecasts of species range shifts under climate change. - Ecol. Lett. 17: 1351-1364, 2014.

Valladares F., Pearcy R.W.: Drought can be more critical in the shade than in the sun: a field study of carbon gain and photoinhibition in a Californian shrub during a dry El Niño year. - Plant Cell. Environ. 25: 749-759, 2002.

Valladares F., Wright J., Lasso E. et al.: Plastic phenotypic response to light of 16 congeneric shrubs from a Panamanian rainforest. - Ecology 81: 1925-1936, 2000.

Vendramin G.G., Fady B., González-Martínez S.C. et al.: Genetically depauperate but widespread: the case of an emblematic Mediterranean pine. - Evolution 62: 680-688, 2008.

Wolf A., Field C.B., Berry J.A.: Allometric growth and allocation in forests: a perspective from FLUXNET. - Ecol. Appl. 21: 1546-1556, 2011.

Yamamoto Y.: Quality control of photosystem II: the mechanisms for avoidance and tolerance of light and heat stresses are closely linked to membrane fluidity of the thylakoids. - Front. Plant Sci. 7: 1136, 2016. 